\title{
Relationships between land use, fertility and Andisol behaviour: examples from volcanic islands
}

\author{
S. Perret ${ }^{1} \&$ M. Dorel
}

\begin{abstract}
Soils developed on volcanic parent materials have many intrinsic qualities favourable to cropping. However, fertility decreases dramatically when they are badly managed. A short review and case studies from Réunion and Guadeloupe highlight the special characteristics of these soils, and their response to management.

The interplay of cropping systems and physical characteristics of Andisols is first considered through the example of Pelargonium and food crop systems in Réunion. Progressive decrease in production and cropping potential shows in falling yields as well as in the overall decline of the system. The example of banana production in Guadeloupe highlights the increase in inputs needed to realise the land's potential and to maintain yields, in particular more tillage and pest treatment.

In both cases, these trends are connected to the co-evolution of soil characteristics and cropping systems. They lead to an increase of risks with less security and less scope in the choice of cropping systems. Technical solutions in the form of erosion-control measures, rotation and planting techniques have been developed and prove to be relevant and consistent in their benefit.
\end{abstract}

Keywords: Andisols, cropping systems, soil fertility, Pelargonium, bananas, Réunion, Guadeloupe

\section{INTRODUCTION}

$\mathrm{A}^{\mathrm{n}}$ ndisols are found mostly in volcanic zones at high altitudes and are widespread throughout the world in these environments.

Initially, they are loose, friable, and often rich in nutrients, and support a wide variety of production systems. However, as they are often sloping and subject to high rainfall, they may suffer erosion and deterioration of the cultivation layer if poorly managed.

The purpose of this paper is to show how land use seems to be a function of soil behaviour and vice versa.

\section{ANDISOLS AND FARMING SYSTEMS IN THE FRANCOPHONE WORLD}

Geography, pedogenesis and the major characteristics

Soils resulting from the break-down and weathering of basic volcanic material cover only small surface areas on a global scale, but they are very widely distributed, especially in wet inter-tropical areas. Being friable and loose to a good depth, free from stones, and well supplied with nutrients, they are usually densely settled. They occupy upland and piedmont zones (East Africa, Cameroon, Central America, Mexico and the Andes) and cover most of certain islands in the West Indies, Indian Ocean, South Pacific, Indonesia and Melanesia (Quantin, 1972), including the French Overseas Depart-

\footnotetext{
${ }^{1}$ Department of Agricultural Economics, Extension and Rural Development, Faculty of Biological and Agricultural Sciences, University of Pretoria, 0002 - Pretoria, South Africa. Fax. +27-117065620. E-mail: perret@cirad.fr CIRAD, Centre de Coopération Internationale en Recherche Agronomique pour le Développement

Corresponding author
}

ments of Réunion, Guadeloupe and Martinique.

Soils with andic behaviour and properties can develop from massive basaltic lavas under heavy rainfall conditions, and more rarely from igneous rocks under certain geochemical conditions (Kimble, 1998). However, they mainly result from the fast weathering of fine basaltic, andesitic or trachytic ashes, and recent pyroclastic deposits, according to two major weathering processes: hydrolysis of volcanic glass and complexing by organic acids.

According to altitude and climate, the same soil sequence is observed on these parent materials in many tropical island settings: the Andisols (Andepts) exhibit a dominant halloysitic character at low altitudes (1200 $\mathrm{mm}$ rainfall), and then become allophanic then gibbsitic with increasing annual rainfall (Colmet-Daage \& Lagache, 1965; Quantin, 1972; Zebrowski, 1975). Table 1 summarizes some physical and chemical data from an Andisol in Réunion and in Guadeloupe.

In the field, the Andisols show two main horizons. One can easily identify the dark A horizon, overlying reddish brown or yellowish brown B horizons. Because of the nature of the ashfall, the horizons are generally horizontal and the transition from $A$ to $B$ horizon is distinct.

Andisols generally have a granular structure in the A horizons due to disturbances of root mat and soil fauna, enhanced by the accumulation of organic matter (5 to $20 \%$ o.m.). The B horizons typically feel loamy and 'puffy', due to low density and to high allophane and water content, and they still contain an important amount of humus (1 to $5 \%$ o.m.), despite their lighter colour. In the field, B horizons appear massive, without aggregates, but rich in microporosity. However, weak subangular blocks can easily be excavated.

Under forest and natural vegetation or on slight slopes, A horizons are usually thick (20 to $60 \mathrm{~cm}$ depth). Under crop- 
Table 1. Chemical and physical characteristics of two Andisols.

Desaturated Andisol (Dystrandept) in food crops in Réunion, $1000 \mathrm{~m}$ altitude, $1500 \mathrm{~mm}$ rainfall, original parent material: trachytic pyroclastic deposit (15 000 years).

\begin{tabular}{llllllrr}
\hline $\begin{array}{l}\text { Depth } \\
(\mathrm{cm})\end{array}$ & Horizon & $\mathrm{pH}_{\mathrm{H} 2 \mathrm{O}}$ & $\begin{array}{l}\mathrm{N} \\
(\%)\end{array}$ & $\begin{array}{l}\mathrm{C} \\
(\%)\end{array}$ & $\begin{array}{l}\mathrm{P} \\
(\mathrm{ppm})\end{array}$ & $\begin{array}{l}\text { CEC } \\
(\mathrm{mmol})\end{array}$ & $\begin{array}{l}\text { Water content } \\
(\%)\end{array}$ \\
\hline $5-15$ & $\mathrm{~A}$ & 5.8 & 7.5 & 8.3 & 596 & 16.3 & 6.75 \\
$40-60$ & $\mathrm{~B}$ & 5.7 & 5.3 & 7.2 & 246 & 10.4 & 120 \\
\hline
\end{tabular}

Desaturated Andisol (Dystrandept) under banana in Guadeloupe, $250 \mathrm{~m}$ altitude, $3500 \mathrm{~mm}$ rainfall, original parent material: andesitic ash deposit (20 000 years).

\begin{tabular}{llllllrr}
\hline $\begin{array}{l}\text { Depth } \\
(\mathrm{cm})\end{array}$ & Horizon & $\mathrm{pH}_{\mathrm{H} 2 \mathrm{O}}$ & $\begin{array}{l}\mathrm{N} \\
(\%)\end{array}$ & $\begin{array}{l}\mathrm{C} \\
(\%)\end{array}$ & $\begin{array}{l}\mathrm{P} \\
(\mathrm{ppm})\end{array}$ & $\begin{array}{l}\text { CEC } \\
(\mathrm{mmol})\end{array}$ & $\begin{array}{l}\text { Water content } \\
(\%)\end{array}$ \\
\hline $0-25$ & $\mathrm{~A}$ & 5.25 & 5.1 & 5.6 & 138 & 6.1 & 80 \\
$25-50$ & $\mathrm{~B}$ & 6.25 & 1.8 & 2.6 & 7 & 2.2 & 158 \\
\hline
\end{tabular}

P: bioavailable phosphorus, by Olsen-Dabin method, CEC: cation exchange capacity, by Hexamin-Cobalt method; C: total carbon, by Anne method; N: total nitrogen by Kjeldahl method. Water content and bulk density measured at field conditions, using in-field core $\operatorname{method}\left(200 \mathrm{~cm}^{3}\right)$.

ping systems, erosion by water is so severe that few relict profiles remain. On steep slopes, nearly all tilled soils have lost their A horizons, leaving B horizons exposed to desiccation.

These soils present unique physical, mechanical or waterrelated properties, that are subject to rapid change under cropping systems. The wide diversity of production systems implemented on these soils is also a characteristic.

\section{Andisols and the cropping systems: two case studies}

In Réunion, andic soils cover half of the total surface area (Raunet, 1991), and constitute $80 \%$ of cultivated land producing sugarcane, Pelargonium, vanilla, fruit trees, cereals, vegetables, fodder crops and forest.

On the leeward coastal slopes, between altitudes of 700 and $1200 \mathrm{~m}$ with annual rainfall of 1200 to $1800 \mathrm{~mm}$ and a marked dry season, Andisols that have formed on ash support rainfed hoed crops, horticultural production (in particular the 'rosat' Pelargonium, for perfume) and food crops. Erosion of A horizons by water is one of the major problems. As an average value over all the cropped Andisols, soil loss in the rainy season may be $50 \mathrm{tha}^{-1}$ year $^{-1}$, and when cyclones occur, as much as $200 \mathrm{tha}^{-1}$ year ${ }^{-1}$ has been measured (Bougère, 1988). This can lead to abandoning plots.

In areas where the rainfall is better distributed, and when the altitude allows, Andisols can also support plantation or export cash crops. On the windward side of Reunion Island it is sugarcane. Under sugarcane, the soils are well protected from erosion but workability is often determined by the location (slope, accessibility, limited trafficability) and the plots are often not easy to reach with harvest and transport machinery (Perret, 1997).

In the Southern part of Guadeloupe, banana plantations replaced sugarcane in the 1970 s. Today systems are most commonly mechanized monocultures, with replanting every 3 or 4 years. Soil fertility is considerably lower than in perennial banana plantations on the leeward coast of the island. Maintaining yields requires frequent applications of pesticide and fertilizer, and the structural state of soil is deteriorating, accompanied by anaerobiosis, necrosis and parasite infestation of rooting systems (Dorel, 1990). The heavy machinery used in replanting accounts for this deterioration.

\section{PHYSICAL PROPERTIES OF ANDISOLS: A BRIEF REVIEW}

The study of Andisols began in the 1950s with issues relating to trafficability (Birrell, 1952). These issues become critical in the case of cultivation on slopes and/or with heavy rainfall.

The physical components of soil fertility discussed below interact closely with crop emergence, the development and function of rooting systems, the choice in cropping systems and trafficability.

\section{Thixotropy and irreversible desiccation}

In volcanic areas in the wet tropics, andic type soils are always found in sequences from brown halloysite soils (Andic Tropept) through slightly desaturated (Eutrandept) then desaturated Andisols (Dystrandept) to allophanic waterlogged Andisols (Hydrandept) in areas of heavy rainfall (ColmetDaage \& Lagache, 1965; Quantin, 1972; Zebrowski, 1975).

Moist andic material, although not rich in lattice clays, contains $80 \%$ of fine non-crystalline material. This results in affinity for water and very high porosity (Paterson, 1976; Rousseaux \& Warkentin, 1976; Egawa, 1977; Wada \& Wada, 1977; Maeda et al., 1977). Despite the high water content, the material is friable and feels moist rather than wet, but adheres strongly to working parts of machinery. Aggregates show considerable structural stability.

Under heavy pressure, the soil abruptly becomes liquid, a phenomenon known as thixotropy. When pressure ceases, the liquid material reverts to its solid state (Perret, 1992). This characteristic directly determines the behaviour of machinery on Andisols leading to limited trafficability, pronounced wheel-slip and destruction of upper soil layers and clogging of working parts of the machinery (Wesley, 1973; Maeda et al., 1983).

When a drying threshold is reached, which varies according to mineral parameters, the hydrated microporous structure of reclaimed Andisols progressively collapses irreversibly. This entails a drop in affinity for water and destruction of clods, accompanied by an increase in the stability of fine aggregates, and the formation of pseudo-sands (Maeda \& Warkentin, 1975). Microporosity diminishes and is replaced in part by inter-particle macroporosity which 
favours accelerated flow of fluids, and mineralization of newly formed organic compounds (Colmet-Daage et al., 1972; Kubota, 1972; Tuncer et al., 1977).

These alterations to the physical environment and water content lead to changes in the microbial population and fauna. Likewise, the transport of the soil by runoff water is facilitated and this triggers erosion. There is a marked structural boundary between the dried-out layer and the moist underlying $\mathrm{B}$ horizon, which results in capillary discontinuity and problems of root penetration (Dorel, 1993).

These processes start as soon as Andisols subjected to a dry season are brought into cultivation. At first they affect the top few centimetres of soil and the subsequent progression depends on the cropping system. Hoeing, which periodically denudes the soil and involves redistribution of the upper layer, increases the depth of the soil layer affected, and tilling triggers these processes throughout the depth of cultivation (Ogawa et al., 1988; Perret, 1992).

Classical soil indicators such as apparent density or total porosity are not sufficient to describe the processes at work in these soils with high water content.

\section{Structural states and cropping systems}

In cultivated horizons, various processes are found: several cycles of desiccation generate a coarse, stable skeleton from the amorphous matrix characterized by continuous microstructure of the $\mathrm{B}$ horizon. Biological activity reinforces this tendency to microaggregation and cultivation involves mechanical forces that can re-fractionate these elements. More marked localized mechanical forces (paths, tracks, regular hoeing and ploughing of upper layers) then cause these structures generated by desiccation to evolve towards a powdery fine silty material, that is easily displaced by wind and water.

Field observation of an Andisol profile reveals the marked structural duality between the horizons. In the moist state, the deep B material presents a smooth, continuous fabric with no visible cracks or aggregates. In contrast, the upper horizon is always clearly structured.

When the original A humus layer is preserved, it often comprises very stable aggregates, mainly produced by fauna. If the deepest weathered $B$ horizon occurs at surface level following erosion/removal of the A horizon, it has a particulate, finer structure, due to irreversible drying. Aggregation then depends mainly on the degree of desiccation reached and mechanical forces involved.

Clods can have very different characteristics. In the case of undisturbed A humic horizons, the clods are porous cohesive units composed of coarse aggregates. Cultivation gradually reduces this cohesion causing these structures to degrade into particulate aggregates produced by the action of implements (Perret, 1992). In the case of mechanized systems in intensive banana or sugarcane production, tightly packed clods are common, as results of high mechanical pressures (Dorel, 1993).

\section{CROPPING SYSTEMS ON ANDISOLS AND FERTILITY: EXAMPLES}

The sustainability of a cropping system can be described using many different indicators: water balance and mineral budgets, field observation of soil profiles, farm work schedule, financial budgets and socioeconomic indicators. The physical properties of Andisols are closely related to agricultural practice. On steep uplands, it is the efficiency of erosion control in cropping systems that chiefly determines sustainability, but mechanized tillage also causes deterioration of fertility.

\section{Shifting or fixed systems}

In traditional shifting Pelargonium cultivation systems in the uplands of Réunion, composted residues from distillation of the Pelargonium plants are all returned to the land, without any extra mineral fertilizer in the early years. Considerable erosion related to hoeing practices is accompanied by a gradual drop in yields and the mineral fertilization that is then introduced has only a palliative effect. Indeed, the deterioration in yields and the fall in work productivity caused by weed encroachment and crop failure lead to abandoning of the fields. New plots are then cleared and cultivated.

Fixed systems, which are taking over from the shifting systems since the end of the 1970s, prove to be catastrophic, since they use the same technology without being able to restore soil fertility by bush fallow.

The land tenancy system known as 'colonage', widely practised in Réunion, constitutes an obstacle to the establishment of anti-erosion measures. Colonage is a kind of annual tenant-farming, in which the farmer shares the produce with the owner of the land, who chooses the cropping, and provides most of the inputs. Fertilizer contributions are small because of cashflow problems that progressively increase. Associated food crops compete with the Pelargonium in the farm work schedule at the time when gaps are replanted (low inputs cause high death rate in Pelargonium, mainly because of soil-borne disease). Weeds grow profusely and farmers attempt control by tillage. For lack of available land, the farmer cannot abandon the plots to clear new ones, and for lack of family labour, he reduces the area under cultivation and runs a very unstable cropping system with low productivity in relation to land and labour. Without mineral fertilizer, Pelargonium cropping declines and is replaced by food crops. It no longer provides enough compost to stem erosion, the more so because compost is earmarked for vegetable production.

Table 2 gives an example of this degradation in Pelargonium cropping systems, through the decrease in overall production of essential oil, as well as through the decrease of land productivity.

Shifting cultivators depend on farming for only a small part of their family income, and although they are today a marginal category, the numbers are still considerable.

Figure 1 shows a model of the overall soil and fertility degradation process under traditional cropping systems in Réunion highlands.

Table 2. The decrease in the production and productivity of Pelargonium essential oil in Réunion (Chastel, 1992).

\begin{tabular}{lccc}
\hline Year & 1972 & 1981 & 1989 \\
\hline Total production $(\mathrm{t})^{\dagger}$ & 120 & 64 & 16 \\
Average yield $^{\dagger}\left(\mathrm{kg} \mathrm{ha}^{-1}\right)$ & 30 & 23 & 10 \\
\hline
\end{tabular}

$\dagger^{\dagger}$ average yield calculated after estimated cropping area. 


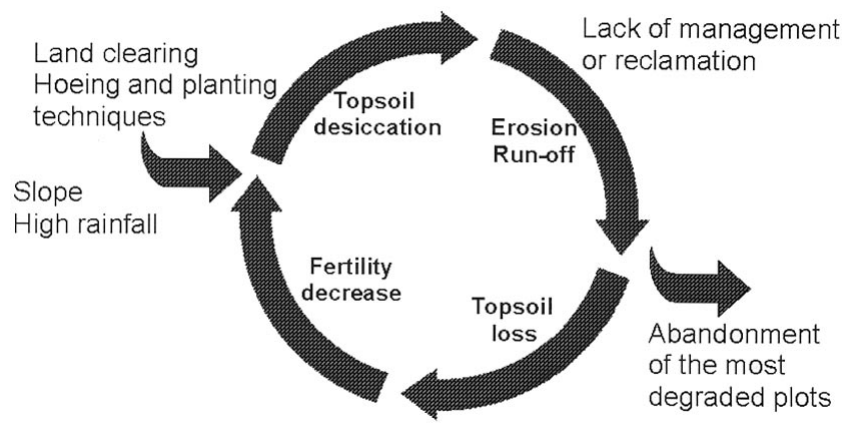

Fig. 1. Degradation processes in traditional agricultural systems growing Pelargonium and food crops on Réunion.

\section{Attempts at intensification}

Land reform has encouraged the development of ownerfarmed systems, efforts to open-up isolated areas and other land developments in Réunion. Owners are turning towards market gardening as soon as they have access to water for irrigation, during the dry winter period. Secondary interrow crops (bean, maize, tomato) are tending to disappear. Manure is provided by introducing beef or goat units onto the farms. These small livestock units also provide mobilizable capital and cash flow reserves when times are difficult. Similarly, Pelargonium cultivation is often maintained because it ensures minimum income whatever the weather conditions and whatever the inputs.

In these systems, large regular application of organic manures and erosion control measures limit soil deterioration. (e.g. planting in rows at optimal densities, plant-covered ridges with fodder cane or agroforestry). The use of herbicides often enables a reduction in hoeing, and frequently the only mechanization is the knapsack sprayer.

Rotation with vegetable crops (often tomato) and sugarcane is often practised where altitude is suitable, it is seen as a means of soil rehabilitation by the farmers, as confirmed by field observations (Perret et al., 1996b).

Weed control is sometimes not achieved at the end of the wet season, and plants that multiply vegetatively can become invasive (e.g. Phalaris arundinacea, Oxalis sp., Cyperus rotondus). Increased workload and shortage of labour can lead the farmer to resort to ploughing to avoid manual hoeing. Good quality ploughing buries these weeds efficiently, but it is rarely well performed by the contractors. Furthermore, other weed species invade the ploughed land (e.g. Raphanus raphanistrum) and erosion problems are aggravated.

In cropping systems based on Pelargonium and food crops, resorting to tillage is not justified by the needs of the crops. Only tobacco makes good use of deep soil preparation, achieving $10-15 \%$ higher yields than with minimum tillage. Pelargonium and food crop yields are generally lower following ploughing, when compared to yields obtained from furrowing or planting by hand in holes (Michellon \& Garin, 1985). Thus, the adoption of no-tillage and permanent cover crops seems to be beneficial. Table 3 summarizes changes in soil physical behaviour related to cropping system. These data show increased permeability resulting from plant cover, and that crop rotation cannot by itself restore soil properties.

Young farmers with training are gradually giving up Pelargonium production to specialize in market gardening in
Table 3. Soil surface properties and behaviour under rainfall simulation, according to cropping practices and surface management (Perret et al, 1996b; Perret, 1992)

\begin{tabular}{lccc}
\hline Soil use and management & $\begin{array}{c}\text { Ksat } \\
\left(\mathrm{mm} \mathrm{h}^{-1}\right)\end{array}$ & $\begin{array}{c}\text { MWD } \\
(\mathrm{mm})\end{array}$ & $\begin{array}{c}\text { Soil lossई } \\
\left(\mathrm{kg} \mathrm{h} \mathrm{ha}^{-1}\right)\end{array}$ \\
\hline $\begin{array}{l}\text { Long-term fallow } \\
\text { Pelargonium monoculture on degraded bare } \\
\text { soil (hoed) }\end{array}$ & $\begin{array}{r}250 \mathrm{a} \\
40 \mathrm{~b}\end{array}$ & $\begin{array}{c}2.50 \mathrm{a} \\
1.10 \mathrm{~b}\end{array}$ & $\begin{array}{c}0-0 \\
208-635\end{array}$ \\
$\begin{array}{l}\text { Pelargonium/ food crop rotation on bare soil } \\
\text { (herbicide) }\end{array}$ & $60 \mathrm{~b}$ & $1.11 \mathrm{~b}$ & $10-207$ \\
\begin{tabular}{l} 
Pelargonium with kikuyu grass cover \\
\hline
\end{tabular} & $105 \mathrm{c}$ & $1.41 \mathrm{c}$ & $0-7$ \\
\hline
\end{tabular}

Ksat and MWD: different letters show significant differences between sites, tested by student's $t$-test at $P=0.1$.

$\dagger$ Ksat: conductivity at saturated soil, in field measurement with disc infiltrometry.

\$ MWD: aggregates' mean weight diameter from laboratory experiments.

${ }^{\S}$ Soil loss: average values from measurement with rainfall simulations under intensities of $45-72 \mathrm{~mm} \mathrm{~h}^{-1}$.

response to grants, the emergence of urban markets and improved communications. The organic matter essential for vegetable production is purchased from penned livestock units at low altitudes, or produced on-farm from cows or goats.

The problem of erosion is often taken into account at field scale (tillage and planting according to contour line, hedges as plot boundaries). But the tillage necessary for vegetable production can cause considerable soil loss in the cyclone season, because of the small crop cover. Minimum tillage and direct drilling, coupled with manure application prove to be effective in such systems (Michellon \& Garin, 1985).

\section{Intensive mechanized production}

Banana plantations were established on the leeward coast of Guadeloupe at the beginning of this century on young soils on steep slopes. Following the decline of sugarcane in the 1970s, banana cultivation spread over the mechanizable level parts of the windward coasts, on older halloysite soils and on Andisols.

Today, the larger part of the banana plantations on Andisols are replanted every 3-4 years and sometimes more frequently. Replanting requires repeated passes by heavy machinery to destroy the previous plantation and then to prepare the soil. The energy required for these operations is considerable: whereas only about $1300 \mathrm{kWh}$ are required in halloysitic clays on Andisols as much as $2300 \mathrm{kWh}$ are used during the $15-20 \mathrm{~h} \mathrm{ha}^{-1}$, (data collected in Guadeloupe; Perret et al., 1996a).

In some upland areas there are also non-mechanized perennial banana plantations. Accounting for only small areas, on some farms, banana is produced in rotation with market garden crops or pineapple.

The impact on rooting systems and soil fertility varies from system to system. In perennial non-mechanized banana, the absence of any mechanized intervention preserves the friable structure of the topsoil, with its high inter-aggregate porosity, and avoids deterioration. The deep horizon (B) has a smoother structure with high tubular porosity. Water and air movements are satisfactory. The roots are healthy and spread down to a depth of $60 \mathrm{~cm}$. 
Table 4. Soil surface characteristics according to banana cropping practices: data range ( $\min -\max )$ or average from field experiments (Dorel, unpublished data).

\begin{tabular}{lcc}
\hline Cropping system & Ksat $\dagger\left(\mathrm{mm} \mathrm{h}^{-1}\right)$ & Macroporosity \\
\hline $\begin{array}{l}\text { Mechanized cropping system, frequent } \\
\text { replanting }\end{array}$ & $36-295$ & 25 \\
\begin{tabular}{l} 
Non-mechanized, perennial plantation \\
\hline
\end{tabular} & $220-480$ & 85 \\
\hline
\end{tabular}

${ }^{\dagger}$ Ksat conductivity at saturated soil, in field measurement with disc infiltrometry.

* Macroporosity $\%$ of overall porosity, laboratory measurement from pressure plate method.

The repeated forces exerted on soils in mechanized cultivation, aggravated by high rainfall (up to $4000 \mathrm{~mm} \mathrm{year}^{-1}$ ), lead to soil structure degradation (Table 4), associated with symptoms of root death due to waterlogging. Most of the healthy functional roots are in the topsoil where the structure is friable. Earthing up by hand produces a volume of soil that is better aerated and favours healthy root development at the base of the plant. However the volume concerned is small, and root development stops on the fringes of the mound causing apex necrosis.

Nematodes, mainly Radolphus similis, which are parasitic on the roots of banana trees, cause considerable loss of production leading to an increase in use of costly nematicides. In intensive monoculture, applications of nematicide are systematic and frequent ( 3 per year) but provide only limited control of the parasite.

When healthy plant stock are obtained from in vitro culture, very low populations of nematodes are observed for the first 20 months, without any treatment. Incidence of root necrosis is under $20 \%$. From the 20th month, reinfestation of certain plots occurs progressively, accompanied by $50 \%$ incidence of necrosis.

Loridat (1989) showed the pathogenic character of Cylindrocladium sp., a fungus found on banana roots. It is frequently detected on Andisols under monoculture. Rotation with a single-year cycle of pineapple does not eliminate it. In contrast, it has never been detected on plots with a rotation of 5 to 10 years pineapple, or on rotation involving Bracharia spp.

Figure 2 shows a model of the soil and fertility degradation process under mechanized banana cropping systems in Guadeloupe.

To improve the sustainability of these banana plantations, work has been done on these rooting problems (Dorel, 1990). The system developed is based on:

(1) planting healthy micropropagated seedlings in soil that has been cleared of disease by a long rotation;

(2) chemical treatment against nematodes based on regular nematode analyses rather than systematic use of chemicals;

(3) increased time intervals between replanting, which reduces frequency of intervention by heavy machinery.

Adoption of cropping systems of this nature, which limits physical and pest damage to roots, has been shown to ensure better use of fertilizer, reduced nematode treatment and, increased productivity of banana plantations with reduced costs.

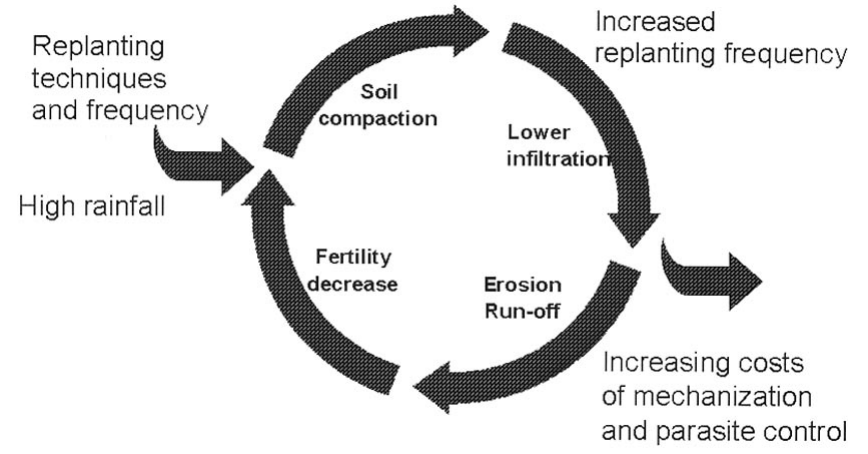

Fig. 2. Degradation processes in intensive banana production in Guadeloupe.

\section{CONCLUSIONS}

Andisols have many intrinsic qualities that favour their use for cropping. However, they prove to be very sensitive and their fertility decreases when they are badly managed. The combined effects of slope and high rainfall lead to a very high but variable erosion risk, according to cropping practices. The absence of erosion control measures, along with hoeing in the traditional cropping systems, and the tilling practices in the intensified market gardening systems, have disastrous consequences. Erosion causes deterioration of soils, a decrease in plant vigour and proliferation of weeds.

In industrial banana units, frequent mechanized operations cause deterioration of soil structure, which has severe consequences on yields and production costs.

In these situations, there are increasing problems of weed control, soil-borne disease, erosion and runoff, with more anoxia, necrosis and parasite infestation of rooting systems, reduced infiltration rate and greater trafficability problems. These show up in falling yields, and in increased inputs (mechanical preparation and pest treatment in particular), and greater risks, i.e. less scope and less security in the choice and implementation of cropping systems, and likewise in achieving yield.

The examples developed here underline the interplay between cropping systems and the physical characteristics of Andisols, and also the permanent interaction between the potential of the soil, husbandry, and sustainability of the systems.

The emergence, or the abandonment, of farming practices enabling soil protection are dependent on socioeconomic factors that are often outside the control of the farmers themselves (land tenure, land distribution, management of labour, economic environment, markets, etc.). The promotion and spread of relevant innovative cropping systems requires those concerned at local level to be familiar with these factors, even if they cannot gain control over them.

The most recent research shows that the deterioration of the structural state and the fertility of Andisols can be reversed by fairly straightforward practices: direct drilling, permanent plant cover during cropping, agroforest hedging, manure and organic matter application (Perret et al., 1996b), the use of Bracharia fallow in rotation with banana (Dorel, 1993).

Current research programmes in Réunion and Guadeloupe consist in building on farmers' experience and husbandry, at the same time as testing and promoting alternative technologies including use of cover crops, agroforestry and planting of more healthy plant material. 


\section{REFERENCES}

BIRRELL, K.S. 1952. Some physical properties of New Zealand volcanic ash soils. In: Proceedings, $I^{\text {st }}$ Conference on Soil Mechanics and Foundation Engineering, Melbourne, pp. 30-34.

BOUGÈRE, J. 1988. Aperçu sur l'érodibilité des andosols cultivés à La Réunion. In: Les andosols de l'ille de La Réunion, préparation d'un programme de recherches pluridisciplinaires, CIRAD-CNRS-INRA-ORSTOM-Université, Séminaire de Saint Denis, 24 May-1 June 1988, pp. 155-162.

CHASTEL, J.M. 1992. La filière géranium à la Réunion: situation et perspectives. In: Le géranium rosat à la Réunion CIRAD édit., Graphica, Saint Denis, pp. 7-14.

Colmet-Daage, F. \& Lagache, P. 1965. Caractéristiques de quelques groupes de sols dérivés de roches volcaniques aux Antilles françaises. Cahiers ORSTOM, série Pédologie III, 91-121.

Colmet-Dange, F. Gautheyrou, J. \& M., DeKimpe, C. \& Fusil, G. 1972. Dispersion et étude des fractions fines de sols à allophanes des Antilles et d'Amérique Latine. $1^{\text {ère }}$ partie: La dispersion. Cahiers ORSTOM, série Pédologie X, 169-191.

Dorel, M. 1990. Influence du milieu et des techniques culturales sur la productivité des bananeraies de Guadeloupe. Enquête-diagnostic. Fruits. $45,237-244$.

DorEL, M. 1993. Travail du sol en bananeraie: cas des andosols. Fruits 48, 7782.

EGAWA, T. 1977. Properties of soils derived from volcanic ash. In: Soils derived from volcanic ash in fapan (eds Y. Ishizuka \& C.A. Black) CIMMYT, Mexico, pp. $10-63$.

KIMBLE, J.M. 1998. Properties and classification of andisols in soil taxonomy: U.S. classification of andisols. In: Proceedings COST 622 meeting, Soil Resources of European Volcanic Systems, Iceland, 5-10 July 1998, pp. 20-25.

KUBOTA, T. 1972. Aggregate-formation of allophanic soils: effect of drying on the dispersion of the soils. Soil Science and Plant Nutrition 18, 79-87.

LORIDAT, P. 1989. Etude de la microflore fongique et des nématodes associés aux nécroses de l'appareil souterrain du bananier en Martinique: mise en évidence du pouvoir pathogène du genre Cylindrocladium. Fruits 44, 587598.

MAEDA, T. \& WARKENTIN, B.P. 1975. Void changes in allophane soils determining water retention and transmission. Soil Science Society of America Proceedings 39, 398-403.

MaEDA, T. TAKenaKa, H. \& WARKENTIN, B.P. 1977. Physical properties of allophane soils. Advances in Agronomy 29, 229-264.

MaedA, T. Soma, K. \& Warkentin, B.P. 1983. Physical and engineering characteristics of volcanic ash soils in Japan compared with those in other countries. Irrigation Engineering and Rural Planning 3, 16-31.
MiChELlON, R. \& GARIN, P. 1985. Recherche-Système dans les Hauts de l'ouest; Synthèse des résultats obtenus: le géranium, le haricot, la pomme de terre, le tabac, le maïs, les fruitiers tempérés. In: Bilan de la Recherche-Système dans les Hauts de l'ouest. Journées du 25-27 November 1985, CIRAD Réunion, pp. 129-201.

OGaWA, K. TAKeUCHI, Y. \& Katayama, M. 1988. Influence of minimum tillage on soil properties and crop yields in gleyic andosol. Research Bulletin of the Hokkaido National Agricultural Experiment Station 150, 57-90.

PATERSON, E. 1976. Specific surface area and pore structure of allophanic soil clays. Clay Minerals 12, $1-9$.

PERRET, S. 1992. Etude des propriétés physiques, hydriques et mécaniques de sols andiques de la Réunion. Facteurs naturels et anthropiques dévolution des horizons cultura ux, implications agronomiques et écologiques. PhD Thesis, Ecole Nationale Supérieure Agronomique de Montpellier.

Perret, S. Pirot, R. \& Dorel, M. 1996a. Préparation mécanisée des sols en bananeraie: itinéraires techniques et performances des matériels sur deux sols volcaniques de Guadeloupe. Notes de recherches, no. 2/96, CIRAD, 7pp.

Perret, S. Michellon, R. TASsin, J. \& Boyer, J. 1996b. Soil rehabilitation and erosion control through agro-ecological practices on Reunion Island (French Overseas Department, Indian Ocean). Agriculture, Ecosystems and Environment 59, 149-157.

PERRET, S. 1997. Trafficabilité et gestion des opérations mécanisées: études expérimentales, modéles et formes d'aide á la décision en culture de canne à sucre. In: Le travail du sol dans les systèmes mécanisés tropica ux (eds R. Pirot, S. Perret \& H. Manichon), Actes du colloque, 11-12 Septembre 1996, Montpellier, CIRAD, collection Colloques, 160pp.

QUANTIN, P. 1972. Les Andosols. Revue bibliographique des connaissances actuelles. Cahiers de l'ORSTOM, série Pédologie X, 273-301.

RAUnET, M. 1991. Le milieu physique et les sols de l'île de La Réunion. Conséquences pour la mise en valeur agricole. CIRAD/Région Réunion, $438 \mathrm{pp}$.

RousSEAUX, J.M. \& WARKENTIN, B.P. 1976. Surface properties and forces holding water in allophane soils. Soil Science Society of America fournal 40, $446-451$.

TunCER, E.R. Lohnes, R.A. \& Demirel, T. 1977. Dessiccation of soils derived from volcanic ash. Transportation Research Records 642, 44-49.

WADA, S.I. \& WADA, K. 1977. Density and structure of allophane. Clay minerals 12, 289-298.

WESLEY, L.D. 1973. Some basic engineering properties of halloysite and allophane clays in Java, Indonesia. Geotechnique 23, 471-494.

ZEBROWSKI, C. 1975. Etude d'une climatoséquence dans l'île de La Réunion. Cahiers ORSTOM, série Pédologie XIII, 255-278.

Received September 1998, accepted after revision January 1999. 